\title{
Literature Review: Peran Kepemimpinan Transformasional dalam Meningkatkan Persepsi Perawat terhadap Handover
}

\author{
Febria Rizky Aulia*, Luky Dwiantoro* \\ *Departemen Ilmu Keperawatan Fakultas Kedokteran, Universitas Diponegoro \\ Email:febriarizkyaulia@students.undip.ac.id; lukydwiantoro@yahoo.com
}

\section{ABSTRACT}

Nurses' perceptions of the implementation of handovers is various. The wrong perception of the implementation of handovers can affect the communication process that threatens patient satisfaction and safety. The head of space as a transformational leader has an important role in influencing nurses' perceptions in the implementation of handovers. The method used in this paper is study literature from several journal articles. The author analyses and synthesizes to describe the role of transformational leadership in increasing nurses' perceptions of the implementation of the handover from the literature study that has been done, the four elements of transformational leadership have a positive role in influencing factors affecting nurses' perceptions. The more positive the impact of transformational leadership on perception factors, the more will have a positive impact on nurses' perceptions. Through the application of transformational leadership, nurses' perceptions and the quality of handovers can improve. It can be concluded that transformational leadership has a positive role in increasing the perception of nurses. This transformational leadership style can be used as a solution and is highly recommended for use by managers / heads of space as one solution to improve nurses' perceptions

Keywords: $\quad$ Nurse leadership, Transformational Leadership, Nurse handover

\section{PENDAHULUAN}

Kegiatan komunikasi yang sering terjadi di dunia pelayanan kesehatan adalah kegiatan serah terima atau handover. Handover merupakan proses komunikasi antara 2 shift perawat untuk memberikan informasi yang berkaitan dengan pasien dan kelanjutan perawatan pasien. ${ }^{1}$ Fakta menunjukkan bahwa komunikasi yang kurang efektif selama handover dapat meningkatkan resiko medication error, ketidakpuasan pasien, penundaan terapi dan membuat waktu perawatan lebih lama. ${ }^{2}$

Persepsi adalah interpretasi dari apa yang dirasakan oleh individu dalam memahami informasi tentang lingkungannya. ${ }^{3}$ Menurut Tjiptono, persepsi adalah penafsiran seseorang setelah melalui proses kognitif tentang apa yang dilihat, dirasakan, didengar, dialami atau dibaca, sehingga mempengaruhi perilaku, pandangan, serta perasaan seseorang. Setiap individu dapat memiliki persepsi yang berbeda meskipun objeknya sama. Persepsi yang positif atau negatif akan ditunjukkan seseorang melalui kinerjanya. ${ }^{4}$ Persepsi menjadi sangat 
penting karena perilaku sesorang didasarkan pada persepsi mereka terhadap realitas itu, bukan mengenai realita itu sendiri. $^{3}$

Setiap orang dapat mempunyai persepsi yang berbeda-beda, hal ini dikarenakan tingkat pendidikan yang berbeda-beda, sikap/perilaku pribadi, motivasi, kepentingan, minat, pengalaman dan harapan terhadap suatu yang dipersepsikan. $^{4}$ Persepsi sangat penting karena perilaku sesorang didasarkan pada persepsi mereka terhadap realitas itu, bukan mengenai realita itu sendiri ${ }^{3}$. Seorang perawat dalam melakukan setiap tindakan sangat dipengaruhi oleh bagaimana persepsi perawat itu sendiri.

Penerapan handover di Indonesia sendiri masih belum dilaksanakan secara baik. Berdasarkan hasil penelitian sebelumnya menunjukkan hasil bahwa pelaksanaan handover belum optimal dan masih banyak informasi/komponen yang dilewatkan selama handover. Hal ini dikarenakan pandangan/pengetahuan yang berbeda-beda dari perawat. ${ }^{5}$ Hasil dari penelitian sebelumnya menyebutkan bahwa sebagian besar perawat menganggap handover tidak penting. Masing-masing perawat juga memiliki pandangan yang berbeda tentang pelaksanaan handover. ${ }^{6}$

Persepsi perawat terkait pelaksanaan handover bisa berbeda-beda setiap orangnya. Persepsi yang salah terkait pelaksanaan handover akan mempengaruhi proses komunikasi itu sendiri ${ }^{6}$, persepsi yang positif atau negatif akan ditunjukkan seseorang melalui kinerjanya. ${ }^{4}$ Ketika perawat mempresepsikan handover itu tidaklah penting, maka perawat akan melakukan handover dengan seadanya dan tidak sesuai dengan standar. Dalam artian, persepsi perawat tentang pelaksanaan handover akan mempengaruhi pelaksanaan handover.

Peran pemimpin juga sangat penting dalam mempengaruhi persepsi/pandangan para anggotanya. Karena keberhasilan suatu organisasi bergantung pada gaya kepemimpinan yang dipakai dalam organisasi tersebut. Gaya kepemimpinan seorang pemimpin menjadi model yang akan mengispirasi para bawahan. Keberhasilan organisasi dalam mencapai tujuan dan sasarannya tergantung pada pemimpin dan gaya kepemipinan yang diterapkannya. $^{7}$

Kepemimpinan transformasional dinilai lebih unggul daripada model kepemimpinan lainnya. Kepemimpinan transformasional merupakan proses mempengaruhi individu untuk mencapai tujuan organisasi dengan mendahulukan kepentingan organisasi. Pemimpin transformasional memilki kemampuan untuk menginspirasi para pengikutnya untuk mengenyampingkan kepentingan pribadi mereka demi kebaikan organisasi dan mereka mampu memiliki pengaruh yang luar biasa pada diri para pengikutnya. ${ }^{8-12}$ Robbins dan Judge menyatakan, pemimpin transformasional adalah pemimpin yang menginspirasi para pengikutnya untuk mengenyampingkan kepentingan pribadi mereka demi kebaikan organisasi dan mereka mampu memiliki pengaruh yang luar biasa pada diri para pengikutnya. ${ }^{8}$

Oleh karena itu, diperlukan study lebih lanjut untuk mengetahui peran dari kepemimpinan transformasional dalam meningkatkan persepsi perawat terhadap pelaksanaan handover

\section{METODE PENELITIAN}

Penulis menggunakan study literature dari beberapa artikel jurnal untuk menyusun tulisan ilmiah ini. Study literatur ini menganalisis tentang persepsi perawat dan menganalisis tentang kepemimpinan transformasional, lalu dilakukan sintesa untuk mendeskripsikan peran kepemimpinan transformasional dalam meningkatkan persepsi perawat terhadap pelaksanaan handover. Sumber pustaka yang digunakan dalam penulisan ini adalah dengan menelaah jurnal dan buku referensi terkait. Pencarian literatur dilakukan secara komprehensif melalui database jurnal dan buku referensi. Tahun penerbitan yang 
digunakan untuk literature review adalah 10 tahun terakhir, yakni 2010-2020. Penelusuran digunakan dengan memasukkan kata kunci sesuai topik.

\section{HASIL DAN PEMBAHASAN}

Semua literature yang sudah ditemukan dari database jurnal dan buku referensi dilakukan penyaringan sesuai kriteria inklusi eksklusi melalui proses Flow Diagram. Setelah proses inklusi eksklusi, terdapat 8 artikel yang memenuhi kriteria. Dari 8 artikel yang ditemukan, selanjutnya dilakukan sintesa dan dianalisa isi dan hasilnya untuk mendapatkan jawaban pertanyaan penelitian ini.

Setiap orang dapat mempunyai persepsi yang berbeda-beda, hal ini dikarenakan tingkat pendidikan yang berbeda-beda, sikap/perilaku pribadi, motivasi, kepentingan, minat, pengalaman dan harapan terhadap suatu yang dipersepsikan. ${ }^{4}$ Persepsi sangat penting karena perilaku sesorang didasarkan pada

persepsi mereka terhadap realitas itu, bukan mengenai realita itu sendiri. ${ }^{3}$

Menurut Robbins dan Judge (2008), terdapat empat indikator kepemimpinan transformasional, yaitu: ${ }^{8-12}$

a. Pengaruh Ideal/Kharismatik (Idealized Influence) yaitu memberikan visi dan misi, memunculkan rasa bangga, mendapatkan respek dan kepercayaan.

b. Motivasi Inspirasional (Inspirational Motivation) yaitu mengkomunikasikan harapan tinggi, menggunakan symbol symbol untuk memfokuskan usaha, mengekspresikan tujuan penting dalam cara yang sederhana.

c. Stimulasi Intelektual (Intellectual Stimulation) yaitu menunjukkan inteligensi, rasional, pemecahan masalah secara hati-hati.

d. Pertimbangan Individual (Individualized Consideration) yaitu menunjukkan perhatian terhadap pribadi, memperlakukan karyawan secara individual, melatih, menasehati.

\section{Transformational Leadership}

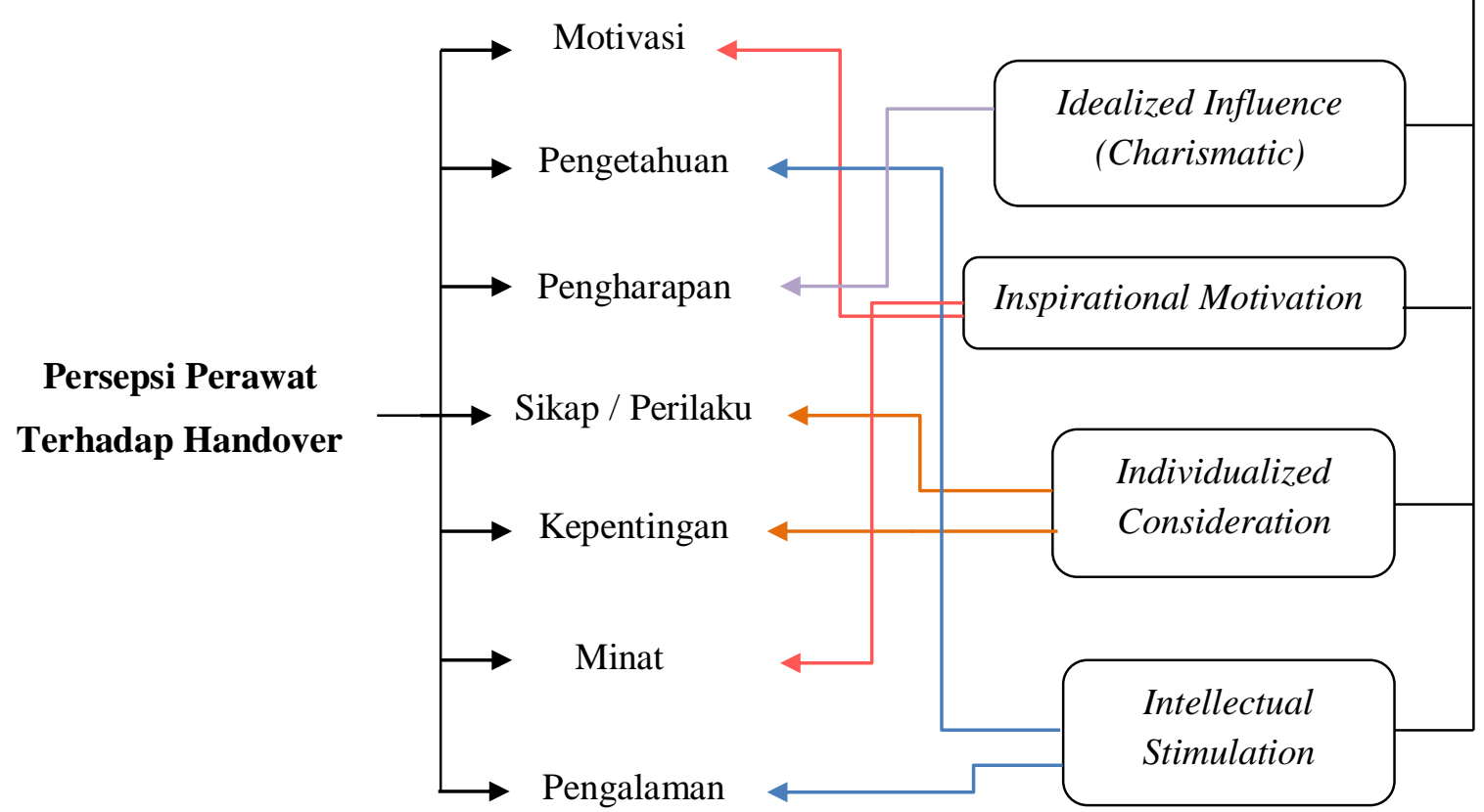

Gambar 1. Proses Transformasional Leadership Dalam Meningkatkan Persepsi Perawat

Perilaku pemimpin melalui pendekatan transformasional untuk meningkatkan persepsi perawat terhadap pelaksanaan 
handover pada hasil diagram analisis hasil diatas dijelaskan sebagai berikut:

\section{a. Idealized Influence (Charismatic)}

Seorang pemimpin yang memiliki karisma, memiliki kemampuan untuk membuat anggotanya memiliki keyakinan yang mendalam pada pemimpinnya, merasa senang dan bangga bisa bekerja bersama dengan pemimpinnya, dan mempercayai kapasitas pemimpinnya. ${ }^{13}$

Kharismatik

transformasional dapat meningkatkan pengharapan perawat, dikarenakan kepemimpinan transformasional berkenaan dengan pengaruh pemimpin terhadap anggotanya. Para anggota merasakan adanya kepercayaan, kebanggaan, loyalitas dan rasa respek terhadap pemimpin dan mereka termotivasi untuk melakukan melebihi apa yang diharapkan ${ }^{8}$. Perilaku kharismatik seorang pemimpin dapat mempengaruhi perilaku karyawan secara positif. Perilaku kharismatik akan memberikan dampak positif terhadap pengharapan perawat. Sikap kharismatik juga dapat berdampak positif terhadap perilaku perawat kearah yang lebih baik. ${ }^{14}$

\section{b. Inspirational Motivation}

Pemimpin transformasional cenderung menyampaikan ide/gagasan yang futuristic, tujuan yang ideal untuk dicapai atau memperbaiki keadaan. Pemimpin mulai memberikan motivasi kepada pengikutnya melalui inspirasi yang diciptakannya. Pemimpin mampu menjelaskan dengan rinci mengenai visi misi serta sasaran program kerjanya kepada semua anggotanya, sebagai akibatnya, para anggota akan merasa antusias untuk berusaha mencapai visi misi tersebut. ${ }^{13}$

Ayu Dewiati melakukan penelitian untuk mengetahui pengaruh kepemimpinan transformasional terhadap motivasi perawat. dari penelitian tersebut disimpulkan bahwa ada pengaruh gaya kepemimpinan transformasional terhadap motivasi dan minat perawat. Hal ini disebabkan bahwa gaya kepemimpinan transformasional adalah pemimpin yang dapat memotivasi karyawan untuk tercapainya kesuksesan dalam bekerja supaya memiliki pengertian yang kuat dalam memberikan visi masa depan dalam organisasi dan memanifestasikan inspirasi yang menggairahkan sebagai perilaku model kepemimpinan yang sesuai. ${ }^{15}$

\section{c. Individualized Consideration}

Pemimpin harus mampu menjadi mentor bagi para anggotanya. Peran sebagai mentor harus dijalankan dengan memperhatikan para anggotanya secara individual dan berorientasi pada pengembangan karakteristik individu. ${ }^{13}$

Penelitian menyebutkan bahwa kepemimpinan transformasional terbukti dapat berpengaruh positif terhadap kepuasan kerja perawat. ${ }^{16}$ Dalam penelitian yang dilakukan oleh Murtiningsing juga ditemukan adanya pengaruh yang sifnifikan terhadap kinerja perawat dengan menerapkan kepemimpinan transformasional. Hal ini disebabkan gaya kepemimpinan transformasional adalah salah satu gaya kepemimpinan yang dapat membangkitkan dan memotivasi karyawan, sehingga dapat berkembang dan mencapai kinerja pada tingkat yang tinggi, melebihi dari apa yang mereka perkirakan sebelumnya. $^{9} \quad$ Terbukti bahwa kepemimpinan transformasional berpengaruh positif terhadap sikap/perilaku perawat.

\section{d. Intellectual Stimulation}

Pemimpin transformasional selalu memiliki cara yang kreatif dalam menyelesaikan masalahnya. Selain itu, mereka juga memiliki cara berfikir yang lebih maju. Pemimpin seringkali memberikan tantangan kepada para anggotanya bagaimana menyelesaikan masalah dengan cara mereka sendiri sehingga mereka terbiasa berfikir kreatif. Dengan cara seperti ini secara tidak langsung seorang pemimpin sudah menginspirasi anggotanya untuk selalu percaya diri mereka sendiri dan berfikir kreatif dalam menghadapi masalah. ${ }^{13}$ 
Penerapan

kepemimpinan transformasional berpengaruh terhadap soft skill perawat (pengetahuan dan pengalaman). Ini dibuktikan dengan penelitian yang dilakukan oleh Tri Hartiti. Dalam penelitiannya, dia menyimpulkan bahwa kepemimpinan transformasional mempunyai korelasi terhadap soft skill perawat pelaksana dalam hal kemampuan beradaptasi, kemampuan berkomunikasi, kemampuan bekerjasama tim, dan ketelitian. ${ }^{17}$

Dari keempat perilaku pemimpin transformasional, semuanya memiliki dampak yang positif terhadap sikap dan persepsi para perawat. Seperti yang sudah diketahui bahwa persepsi sangat penting karena perilaku sesorang didasarkan pada persepsi mereka terhadap realitas itu, bukan mengenai realita itu sendiri. ${ }^{3}$

Penerapan gaya kepemimpinan transformasional ini, maka pemimpin dapat memberikan contoh, motivasi, pengharapannya, dan pandangannya terhadap pelaksanaan handover. Peningkatan persepsi perawat terhadap pelaksanaan handover itu sendiri, maka pelaksanaan handoverpun akan lebih baik dan lebih optimal. Terlewatnya komponen saat pelaporan, kesalahan pelaporan pasien, dan durasi waktu yang lama saat pelaporan tidak akan ada lagi. Semakin pemimpin transformasional mampu menginspirasi para perawat terkait pelaksanaan handover, maka semakin baik persepsi perawat terhadap pelaksanaan handover, dan semakin baik pula pelaksanaan handover itu sendiri.

\section{KESIMPULAN}

Dapat disimpulkan bahwa kepemimpinan transformasional mempunyai peran yang positif terhadap persepsi para perawat. Gaya kepemimpinan transformasional ini bisa dijadikan sebuah solusi dan sangat disarankan untuk digunakan oleh para manajer/kepala ruang sebagai salah satu solusi untuk meningkatkan persepsi perawat. Pemimpin transformasional dapat memberikan contoh, motivasi, pengharapannya, dan pandangannya terhadap pelaksanaan handover melalui keempat unsur kepemimpinan transformasional. Pemimpin transformasional memilki kemampuan untuk menginspirasi para pengikutnya dan memiliki pengaruh yang luar biasa pada pengikutnya, diharapkan melalui penerapan kepemimpinan transformasional ini dapat meningkatkan persepsi perawat dan kualitas handover dapat meningkat.

\section{UCAPAN TERIMA KASIH}

Terimakasih peneliti sampaikan kepada dosen pembimbing yaitu Dr. Luky Dwiantoro S.Kp. M.Kep yang sudah membimbing peneliti dengan baik. Dan terimakasih kepada pihak yang sudah membantu dari awal sampai akhir proses penelitian.

\section{DAFTAR PUSTAKA}

1. Hidajah U, Harnida H. Peran Komunikasi SBAR Dalam Pelaksanaan Handover di Ruang Rawat Inap RSPS. J Keperawatan dan Kebidanan. 2016;72-81.

2. Malekzadeh J, Mazluom SR, Etezadi T, Tasseri A. A standardized shift handover protocol: improving nurses' safe practice in intensive care units. $\mathbf{J}$ caring Sci [Internet]. 2013;2(3):17785. Available from: http://www.ncbi.nlm.nih.gov/pubmed/ 25276725\%0Ahttp://www.pubmedcen tral.nih.gov/articlerender.fcgi?artid=P MC4134157

3. Haryanti T, Pujianto TI, Adinatha NN. Analisis Pengaruh Persepsi Perawat Pelaksana Tentang Fungsi Manajerial Kepala Ruang Terhadap Pendokumentasian Asuhan Keperawatan Di Ruang Rawat Inap Rumah Sakit Swasta Di Semarang. J Manaj Keperawatan. 2013;1(2):131-7.

4. Trimumpuni EN. Analisis Pengaruh Persepsi Mutu Pelayanan Asuhan Keperawatan terhadap Kepuasan Klien 
Rawat Inap di RSU Puri Asih Salatiga. Tesis J Undip [Internet]. 2009; Available from: http://eprints.undip.ac.id/17427/

5. Astuti N, Ilmi B. Penerapan Komunikasi Situation, Background, Assesment, Recomendation (SBAR) Pada Perawat Dalam Melaksanakan Handover. J Nurs Pract. 2019;3(1):4251.

6. Dewi Arianti N. Gambaran Komunikasi SBAR Saat Transfer Pasien Pada Perawat Di RSUD K.R.M.T. Wongsonegoro. Universitas Diponegoro; 2017.

7. Nursalam. Manajemen Keperawatan Aplikasi Keperawatan Profesional Edisi 4. 2014;342.

8. Suweko H, Dwiantoro L. Kepemimpinan Transformasional Dalam Meningkatkan Kepuasan Kerja Perawat. J Ilmu Keperawatan dan Kebidanan. 2011;2011(1):71-85.

9. Murtiningsih. Pengaruh Gaya Kepemimpinan Transformasional Pada Kinerja Perawat Rumah Sakit Islam Siti Aisyah Madiun. J Ekon Manaj Sumber Daya. 2015;17(2):54-65.

10. Purnomo L. Pengaruh Gaya Kepemimpinan Kepala Ruang Terhadap Kepuasan Kerja Perawat. Semin Nas dan Call Pap. 2015;225-36.

11. Wayan. Manajemen keperawatan. 2006;117.

12. Nursalam. Manajemen Keperawatan Aplikasi dalam Praktik Keperawatan Profesional Edisi 3. Salemba Medika. 2011. 1-359 p.

13. Budi Nugroho Y. Kepemimpinan
Untuk Mahasiswa : Teori dan Aplikasi. Jakarta: Unika Atma Jaya; 2019. 202 p.

14. Elmonita Y, Dwiantoro L. Transformasional leadership dalam meningkatkan perilaku edukatif perawat dalam pelayanan. Semin Nas dan Call Pap [Internet]. 2017;182-91. Available from: http://eprints.undip.ac.id/61162/1/12.p df

15. Savitri AD. Pengaruh Gaya Kepemimpinan Transformasional Terhadap Motivasi Kerja Perawat Di Instalasi Rawat Inap (Irna) II RSUD Dr. Saiful Anwar Malang. 2014;18(1).

16. Arifiani R, Astuti E, Ruhana I. Pengaruh Kepemimpinan Transformasional Terhadap Organizational Citizenship Behavior Dan Kepuasan Kerja (Studi pada Tenaga Perawat RSUD. Dr. Saiful Anwar Malang). J Adm Bisnis S1 Univ Brawijaya. 2016;33(1):127-35.

17. Hartiti T. Peningkatan Softskill Perawat Melalui Kepemimpinan Transformasional Kepala Ruang Pada Rs Swasta Di Semarang. J Manaj Keperawatan. 2013;1(2):111397. 